\title{
FREE FATTY ACID MOBILIZATION BY NEUROADRENERGIC STIMULATION IN MAN *
}

\author{
-By JAMES T. HAMLIN, III, † ROGER B. HICKLER AND ROBERT G. HOSKINS $\ddagger$ \\ (From the Medical Service and the Pearl Geriatric Unit of the Peter Bent Brigham Hospital \\ and the Department of Medicine, Harvard Medical School, Boston, Mass.)
}

(Submitted for publication September 16, 1959; accepted December 4, 1959)

A role of the sympathetic nervous system in the metabolism of adipose tissue has been suggested by clinical observations and by animal denervation experiments (1). The recent observations of the mobilization of free fatty acids ${ }^{1}$ (FFA) by norepinephrine (NE) in vitro (2) and in vivo $(3,4)$ add presumptive evidence for a function of the sympathetic nervous system in the transport of fatty acids. To elucidate further the role of the sympathetic nervous system in fatty acid transport, the effect of a standard physiological stress on plasma FFA concentration was studied.

Previous work has shown that the normal individual defends against the orthostatic stress of a $60^{\circ}$ upright tilt by an increase in diastolic blood pressure and pulse rate. This response is probably mediated by the autonomic nervous system through baroceptor reflexes and is accompanied by a rise in plasma $\mathrm{NE}$ concentration (5). These responses reflect an increase in neuroadrenergic activity; and, as a corollary, are absent in individuals after sympathectomy and in patients with primary autonomic insufficiency.

It is the purpose of this report to present the effects of neuroadrenergic stimulation produced by orthostatic stress on plasma FFA concentration.

\section{METHODS}

The response of plasma FFA and $\mathrm{NE}$ to tilting was studied in 6 normal subjects, in 1 patient with bilateral adrenalectomy, and in 1 patient with primary autonomic

* Supported in part by grants from the John A. Hartford Foundation, Inc., New York, N. Y.

$\uparrow$ Public Health Service Postdoctoral Fellow, National Institute of Mental Health, Bethesda, Md. Present address: New York Medical College, Flower and Fifth Avenue Hospitals, New York, N. Y.

$\$$ Public Health Service Postdoctoral Fellow, National Heart Institute, Bethesda, Md.

1 The term "free fatty acids" is used here in place of the terms "nonesterified fatty acids" and "unesterified fatty acids" previously used to describe this lipid fraction. insufficiency. All studies were carried out with fasting subjects in the supine position on a tilt table. An indwelling needle was secured in an antecubital vein and was kept patent for the collection of blood specimens by a slow infusion of sterile isotonic saline. Pulse rate and blood pressure were recorded until a steady state was achieved. The subject was then tilted $60^{\circ}$ upright for 30 minutes. Pulse and blood pressure were recorded at regular intervals throughout the experiment. Blood specimens for plasma FFA and NE were drawn $10 \mathrm{~min}$ utes before and immediately prior to tilting to $60^{\circ}$ upright and at 2.5, 5, 10, 20 and 30 minutes in the upright position. The subject was then returned to the supine position and another blood specimen was drawn $10 \mathrm{~min}$ utes later.

The effect of an adrenolytic agent, phentolamine methanesulfonate, ${ }^{2}$ on the plasma FFA response to tilting was studied in 3 normal individuals. Each subject served as his own control. The FFA and NE responses were determined during a 30 minute control tilt after which $5 \mathrm{mg}$ of phentolamine was administered intravenously and the subject was tilted a second time. One subject was studied again 1 month later with a dose of $10 \mathrm{mg}$ of phentolamine.

The effect of 2 successive tilts was studied in 3 normal subjects without administering phentolamine prior to the second tilt.

All blood specimens were collected in tubes with phenol-free heparin as the anticoagulant. Specimens were kept in ice and at the end of the experiment were centrifuged and the plasma stored at $-18^{\circ} \mathrm{C}$ for subsequent FFA and NE determinations. FFA concentrations were determined by the method of Dole (6) and the $\mathrm{NE}$ concentrations by the method of Weil-Malherbe and Bone (7) as modified by Aronow and Howard (8).

\section{RESULTS}

The response of plasma FFA concentration to tilting in six normal individuals is illustrated in Figures $1 \mathrm{~A}$ and $1 \mathrm{~B}$ and in Table $\mathrm{I}$. In each case there was a rise above control levels in $2.5 \mathrm{~min}$ utes and a peak increment in 20 to 30 minutes. The FFA concentration of the specimen collected immediately prior to tilting was used as the con-

\footnotetext{
${ }^{2}$ Kindly supplied by the Ciba Pharmaceutical Co. as Regitine.
} 


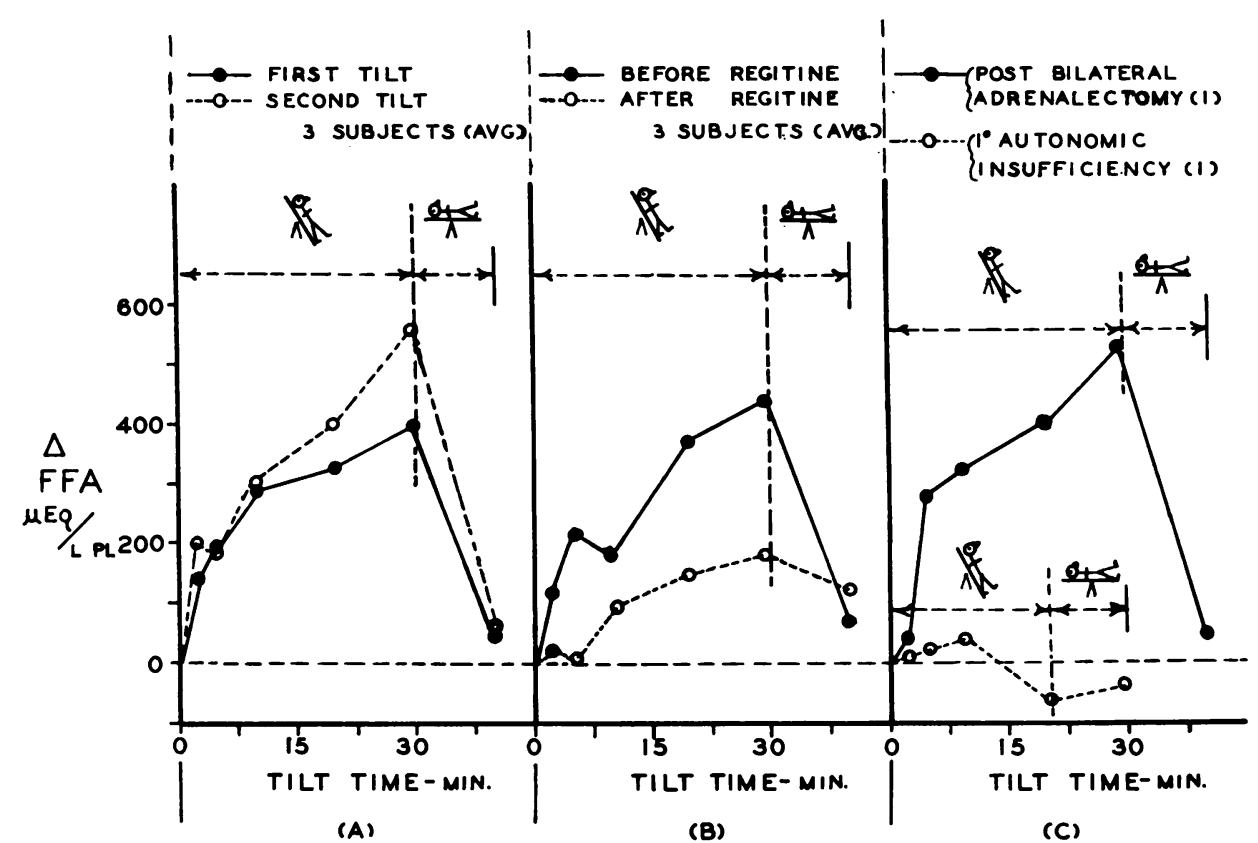

Fig. 1. Relationship between orthostatic stress and plasma FFA concentration. (A) Effect of successive tilting; (B) effect of Regitine; (C) effect of bilateral adrenalectomy and primary autonomic insufficiency.

trol level. Maximal increments above control values varied from 250 to $870 \mu \mathrm{Eq}$ per $\mathrm{L}$ with a mean increment of $480 \mu \mathrm{Eq}$ per L, an increase of approximately 70 per cent in plasma FFA concentration. After returning the subject to $0^{\circ}$, the FFA concentration fell rapidly and approached

TABLE I

Free fatty acid and norepinephrine response to 30 minute tilt *

\begin{tabular}{|c|c|c|c|c|c|c|c|c|c|c|c|c|c|c|c|c|}
\hline & & \multicolumn{2}{|c|}{ Control } & \multicolumn{2}{|c|}{$2.5 \mathrm{~min}$} & \multicolumn{2}{|c|}{$5 \mathrm{~min}$} & \multicolumn{2}{|c|}{$10 \mathrm{~min}$} & \multicolumn{2}{|c|}{$20 \mathrm{~min}$} & \multicolumn{2}{|c|}{$30 \mathrm{~min}$} & \multicolumn{2}{|c|}{$40 \mathrm{~min}$} & \multirow[b]{2}{*}{ Remarks } \\
\hline \multicolumn{2}{|c|}{ Subject } & FFA & $\mathrm{NE}$ & FFA & $\mathrm{NE}$ & FFA & $\mathrm{NE}$ & FFA & $\mathrm{NE}$ & FFA & $\mathrm{NE}$ & FFA & $\mathrm{NE}$ & FFA & $\mathrm{NE}$ & \\
\hline & & \multicolumn{2}{|c|}{$\mu E q / L \mu g / L$} & \multicolumn{2}{|c|}{${ }_{\mu} E q / L \mu g / L$} & \multicolumn{2}{|c|}{$\mu E q / L \mu g / L$} & \multicolumn{2}{|c|}{$\mu E q / L \mu g / L$} & \multicolumn{2}{|c|}{$\mu E q / L \mu g / L$} & \multicolumn{2}{|c|}{$\mu E q / L \mu g / L$} & \multicolumn{2}{|c|}{$\mu E q / L \mu g / L$} & \\
\hline RBH & $\stackrel{(1)}{(2) \dagger}$ & $\begin{array}{l}435 \\
745\end{array}$ & $\begin{array}{l}3.1 \\
3.1\end{array}$ & $\begin{array}{l}580 \\
785\end{array}$ & $\begin{array}{l}3.1 \\
3.1\end{array}$ & $\begin{array}{l}690 \\
740\end{array}$ & $\begin{array}{l}3.1 \\
3.9\end{array}$ & $\begin{array}{l}640 \\
860\end{array}$ & $\begin{array}{l}4.0 \\
4.4\end{array}$ & $\begin{array}{l}865 \\
945\end{array}$ & $\begin{array}{l}2.6 \\
4.0\end{array}$ & $\begin{array}{r}1,310 \\
950\end{array}$ & $\begin{array}{l}3.2 \\
3.8\end{array}$ & $\begin{array}{l}680 \\
850\end{array}$ & $\begin{array}{l}4.1 \\
4.4\end{array}$ & Normal subject \\
\hline JW & $\begin{array}{l}(1) \\
(2) \dagger\end{array}$ & $\begin{array}{l}565 \\
485\end{array}$ & $\begin{array}{l}1.5 \\
0.6\end{array}$ & $\begin{array}{l}635 \\
510\end{array}$ & $\begin{array}{l}2.7 \\
1.2\end{array}$ & $\begin{array}{l}740 \\
500\end{array}$ & $\begin{array}{l}3.0 \\
0.7\end{array}$ & $\begin{array}{l}645 \\
545\end{array}$ & $\begin{array}{l}2.5 \\
0.7\end{array}$ & $\begin{array}{l}880 \\
590\end{array}$ & $\begin{array}{l}1.8 \\
0.7\end{array}$ & $\begin{array}{l}700 \\
680\end{array}$ & $\begin{array}{l}2.4 \\
1.4\end{array}$ & $\begin{array}{l}495 \\
655\end{array}$ & $\begin{array}{l}1.4 \\
0.3\end{array}$ & Normal subject \\
\hline RGH & $\begin{array}{l}(1) \\
(2) \dagger\end{array}$ & $\begin{array}{r}665 \\
1,000\end{array}$ & $\begin{array}{l}5.3 \\
5.6\end{array}$ & $\begin{array}{l}800 \\
990\end{array}$ & $\begin{array}{l}5.1 \\
5.4\end{array}$ & $\begin{array}{l}825 \\
955\end{array}$ & $\begin{array}{l}6.2 \\
5.7\end{array}$ & $\begin{array}{l}1,055 \\
1,035\end{array}$ & $\begin{array}{l}5.6 \\
5.8\end{array}$ & $\begin{array}{l}1,220 \\
1,545\end{array}$ & $\begin{array}{l}6.8 \\
6.2\end{array}$ & $\begin{array}{l}1,255 \\
1,563\end{array}$ & $\begin{array}{l}2.8 \\
5.3\end{array}$ & $\begin{array}{r}970 \\
1,590\end{array}$ & $\begin{array}{l}5.3 \\
5.6\end{array}$ & Normal subject \\
\hline & $\begin{array}{l}(3) \ddagger \\
(4) \S\end{array}$ & $\begin{array}{l}735 \\
785\end{array}$ & $\begin{array}{l}3.7 \\
4.6\end{array}$ & $\begin{array}{l}810 \\
735\end{array}$ & $\begin{array}{l}4.1 \\
4.6\end{array}$ & $\begin{array}{l}915 \\
720\end{array}$ & 4.1 & $\begin{array}{l}945 \\
815\end{array}$ & $\begin{array}{l}4.1 \\
1.4\end{array}$ & $\begin{array}{r}1,150 \\
865\end{array}$ & 2.7 & $\begin{array}{r}1,005 \\
885\end{array}$ & $\begin{array}{l}7.3 \\
3.2\end{array}$ & $\begin{array}{l}725 \\
815\end{array}$ & 4.6 & \\
\hline LT & $\begin{array}{l}(1) \\
(2)\end{array}$ & $\begin{array}{l}830 \\
837\end{array}$ & & $\begin{array}{r}880 \\
1,029\end{array}$ & & 959 & & $\begin{array}{l}1,030 \\
1,144\end{array}$ & & $\begin{array}{l}1,145 \\
1,227\end{array}$ & & $\begin{array}{l}1,135 \\
1,332\end{array}$ & & $\begin{array}{r}835 \\
1,046\end{array}$ & & Normal subject \\
\hline FM & $\begin{array}{l}(1) \\
(2)\end{array}$ & $\begin{array}{l}720 \\
680\end{array}$ & $\begin{array}{l}5.9 \\
6.6\end{array}$ & $\begin{array}{l}770 \\
870\end{array}$ & 6.6 & 735 & 6.8 & $\begin{array}{l}920 \\
855\end{array}$ & $\begin{array}{l}5.9 \\
8.0\end{array}$ & $\begin{array}{l}790 \\
950\end{array}$ & $\begin{array}{l}5.9 \\
6.3\end{array}$ & 970 & 6.3 & $\begin{array}{l}680 \\
705\end{array}$ & $\begin{array}{l}5.4 \\
5.3\end{array}$ & Normal subject \\
\hline RF & $\begin{array}{l}(1) \\
(2)\end{array}$ & $\begin{array}{l}635 \\
740\end{array}$ & $\begin{array}{l}2.1 \\
2.1\end{array}$ & $\begin{array}{l}910 \\
965\end{array}$ & $\begin{array}{l}2.0 \\
1.8\end{array}$ & $\begin{array}{l}965 \\
975\end{array}$ & $\begin{array}{l}2.2 \\
2.2\end{array}$ & $\begin{array}{l}1,035 \\
1,170\end{array}$ & $\begin{array}{l}2.1 \\
2.2\end{array}$ & $\begin{array}{l}1,145 \\
1,275\end{array}$ & $\begin{array}{l}4.6 \\
1.9\end{array}$ & $\begin{array}{l}1,200 \\
1,390\end{array}$ & $\begin{array}{l}1.5 \\
5.2\end{array}$ & $\begin{array}{l}740 \\
730\end{array}$ & 2.2 & Normal subject \\
\hline PT & & 530 & 0.5 & 560 & 0.8 & 795 & 0.8 & 845 & 0.7 & 920 & 2.1 & 1,050 & 0.5 & 545 & 0.5 & $\begin{array}{l}\text { Bilateral } \\
\text { adrenalectomy }\end{array}$ \\
\hline WB & & 970 & 4.6 & 1,025 & 6.5 & 1,040 & 5.6 & 1,055 & & 955 & 5.1 & 985 & 3.7 & & & $\begin{array}{l}\text { Primary autonomic } \\
\text { insufficiency- subject } \\
\text { fainted and tilt } \\
\text { terminated at } 18 \mathrm{~min}\end{array}$ \\
\hline
\end{tabular}

* FFA $=$ free fatty acids; $\mathrm{NE}=$ norepinephrine. 
control concentrations within 10 minutes. Plasma $\mathrm{NE}$ concentrations rose at least $1 \mu \mathrm{g}$ per $\mathrm{L}$ plasma in each case after tilting (mean increment above control, $1.8 \mu \mathrm{g}$ per L plasma), but showed no consistent temporal relationship between peak FFA response and peak circulating NE concentration.

The effect of phentolamine methanesulfonate on the FFA response in three normal individuals is shown in Figure 1B. In each case the FFA rise after phentolamine was depressed as compared with that of the first tilt. A rise in plasma NE concentration occurred in response to tilting both before (mean increase $2.0 \mu \mathrm{g}$ per L) and after (mean increase $0.7 \mu \mathrm{g}$ per L) phentolamine. The subject studied a second time (one month later) with $10 \mathrm{mg}$ of phentolamine showed a greater depression of the FFA response than that which occurred with $5 \mathrm{mg}$ of phentolamine.

The results of two successive tilts without receiving phentolamine prior to the second tilt are shown in Figure 1A. In each case the plasma FFA response during the second tilt exceeded that of the first.

The plasma FFA response to tilting in a patient with bilateral adrenalectomy for Cushing's disease two years previously, and now receiving $50 \mathrm{mg}$ of cortisone daily, is shown in Figure 1C. The FFA response was found to be close to the mean response of the normal individuals. The postadrenalectomy patient showed a normal rise in plasma NE (1.6 $\mu \mathrm{g}$ per L) after tilting.

The patient with primary autonomic insufficiency showed essentially no increase in plasma FFA concentration in response to tilting (Figure 1C). His blood pressure gradually fell during the upright tilt and at 18 minutes he fainted. On two previous tilt studies his plasma NE increment was found to be less than $1 \mu \mathrm{g}$ per $\mathrm{L}$ (9).

\section{DISCUSSION}

It is well established that in the fasting state plasma FFA serves as a transport form of fat available for oxidative metabolism (10). In the fasting individual the adipose tissue is the major source of plasma FFA and it represents a potential pool of readily mobilizable substrate for energy requirements. The results reported here indicate that FFA can be mobilized in response to orthostatic stress. The FFA rise accompanies the hemodynamic responses and the increase in circulating NE concentrations and would seem to result from increased neuroadrenergic activity. An obligatory role of the adrenal medulla in mediating the FFA response to tilting is ruled out by the normal response to tilting in the postadrenalectomy patient. This indicates that the FFA mobilization secondary to tilting is not dependent upon the release of adrenal medullary hormones. The normal NE response to tilting in the patient after bilateral adrenalectomy indicates that the increase in circulating $\mathrm{NE}$ concentration after tilting is, for the most part, a "spill-over" of NE released at adrenergic nerve endings. The rise in circulating $\mathrm{NE}$ concentration is probably a reflection of neuroadrenergic activity. The possibility that the elevation in plasma $\mathrm{NE}$ concentration after tilting may represent decreased destruction rather than increased production of $\mathrm{NE}$ is not ruled out by these experiments, but this seems unlikely in view of the reported release of $\mathrm{NE}$ by the adrenergic nerves after various forms of stimulation (11).

The fact that the plasma FFA response during the second of the two successive tilts was greater than the response in the first tilt indicates that the decrease in the FFA response after phentolamine was not due to fatigue of the mobilization mechanism by two successive tilts.

The blocking action of phentolamine and the markedly diminished response in a patient with autonomic insufficiency suggest that mobilization of FFA from adipose tissue under the stimulus of orthostatic stress requires an intact adrenergic nerve supply and an available receptor site in adipose tissue. These results are in agreement with findings of others that phentolamine in vitro will block the release of FFA from rat epididymal fat pads by epinephrine (3) and that the mobilization of FFA may be actuated by emotional arousal and be depressed by ganglionic blocking agents (12).

From the evidence presented it would appear that neuroadrenergic stimulation in man is associated with an increase in plasma free fatty acid concentration. This supports the conception that the autonomic nervous system plays a significant role in the mobilization of free fatty acid in man. 


\section{SUMMARY}

1. Plasma free fatty acid concentrations increased in normal fasting individuals in response to neuroadrenergic activity stimulated by the orthostatic stress of a $60^{\circ}$ upright tilt.

2. This response was present in a patient following bilateral adrenalectomy but was greatly diminished in a patient with primary autonomic insufficiency.

3. The response of plasma free fatty acids to tilting can be diminished by the administration of an adrenolytic agent, phentolamine.

4. These results support the concept that the autonomic nervous system plays a significant role in the mobilization of free fatty acid in man.

\section{REFERENCES}

1. Wertheimer, E., and Shapiro, B. The physiology of adipose tissue. Physiol. Rev. 1948, 28, 451.

2. White, J. E., and Engel, F. L. A lipolytic action of epinephrine and norepinephrine on rat adipose tissue in vitro. Proc. Soc. Exp. Biol. (N. Y.) 1958, 99, 375.

3. Schotz, M. C., and Page, I. H. Effect of norepinephrine on plasma nonesterified fatty acids (NEFA) and the release of NEFA from rat epididymal adipose tissue. Fed. Proc. 1959, 18, 139.

4. Goldfien, A., and Havel, R. J. The effects of norepinephrine and epinephrine on unesterified fatty acid metabolism. J. clin. Invest. 1959, 38, 1007.

5. Hickler, R. B., Wells, R. E., Jr., Tyler, H. R., and Hamlin, J. T., III. Plasma catechol amine and electroencephalographic responses to acute postural change. Amer. J. Med. 1959, 26, 410.

6. Dole, V. P. A relation between non-esterified fatty acids in plasma and the metabolism of glucose. J. clin. Invest. 1956, 35, 150.

7. Weil-Malherbe, H., and Bone, A. D. Chemical estimation of adrenaline-like substances in the blood. Biochem. J. 1952, 51, 311.

8. Aronow, L., and Howard, F. A. Improved fluorometric technique to measure changes in adrenal epinephrine-norepinephrine output caused by veratrum alkaloids. Fed. Proc. 1955, 14, 315.

9. Hickler, R. B., Thompson, G. R., Fox, L. M., and Hamlin, J. T., III. Successful treatment of orthostatic hypotension with 9-alphafluorohydrocortisone. New Engl. J. Med. 1959, 261, 788.

10. Fredrickson, D. S., and Gordon, R. S., Jr. Transport of fatty acids. Physiol. Rev. 1958, 38, 585.

11. von Euler, U. S. Noradrenaline. Springfield, Ill., Charles C Thomas, 1956.

12. Bogdonoff, M. D., Weissler, A. M., Merritt, F. L., Jr., Harlan, W. R., and Estes, E. H., Jr. The role of the autonomic nervous system in human lipid metabolism. J. clin. Invest. 1959, 38, 989. 